\title{
Diversity of Pentatomoidea (Hemiptera) in riparian forests of southern Brazil: taller forests, more bugs ${ }^{1}$
}

\author{
Milton de S. Mendonça, Jr. ${ }^{2}$, Cristiano Feldens Schwertner ${ }^{3} \&$ Jocélia Grazia ${ }^{3}$
}

${ }^{1}$ Contribution n. 549 of the Department of Zoology, UFGRS.

${ }^{2}$ Department of Ecology, Instituto de Biociências, UFRGS. Av. Bento Gonçalves, 9500, Bloco IV, Bairro Agronomia, Caixa Postal 15007, 91540-000 Porto Alegre-RS, Brazil. milton.mendonca@ufrgs.br

${ }^{3}$ Department of Zoology \& PPG-Biologia Animal, Instituto de Biociências, UFRGS. Av. Bento Gonçalves, 9500, Bloco IV, Bairro Agronomia, 91501-970 Porto Alegre-RS, Brazil CFS: CAPES fellowship. acrosternum@yahoo.com.br; JG: CNPq fellowship. jocelia@ufrgs.br

\begin{abstract}
Diversity of Pentatomoidea (Hemiptera) in riparian forests of southern Brazil: taller forests, more bugs. Riparian forests are important features of any ecosystem, especially on grassland and savannah vegetation types. However, riparian forests in southernmost Brazil have received much less attention than elsewhere. This is the first quantitative study of pentatomoid (Hemiptera) diversity in the Pampa biome, surveying riparian forests of brooks and rivers in the environs of the municipality of Bagé, Rio Grande do Sul state, southern Brazil. The aim was two-fold: taxonomic characterization of the fauna and a primary ecological study of bug diversity. Sweeping net and beating tray were used to sample trees and shrubs on the border of sampling sites; sampling was carried out during three consecutive days, from March $28^{\text {th }}$ to $30^{\text {th }}$ 2006. Overall 154 individuals of 32 species of Pentatomoidea were captured, almost all species are new records for the local fauna. Taller forest canopy sites had higher abundance overall and higher species richness than shorter forest canopy sites. Of the 32 species, 11 were singletons and four were doubletons. There were no differences for pentatomoid species composition between the two environments differing in vegetation structure. Association to the Pampa biome of the most abundant species found are discussed. Although based on a rapid assessment protocol of faunal inventories, our results add important bioecological information to the pentatomoid fauna of the Pampa biome, especially associated to riparian forests.
\end{abstract}

KEYWORDS. Acanthosomatidae; Corimelaenidae; Pentatomidae; Scutelleridae; Pampa biome.

RESUMO. Diversidade de Pentatomoidea (Hemiptera) em matas ripárias do sul do Brasil: florestas mais altas têm mais percevejos. Matas ripárias são partes importantes de qualquer ecossistema, especialmente aqueles com predomínio de campos e savanas. No entanto, matas ripárias na região sul do Brasil têm recebido pouca atenção. Este trabalho representa o primeiro estudo quantitativo sobre a diversidade de percevejos-do-mato (Hemiptera, Pentatomoidea) no bioma Pampa, a partir do levantamento em matas ripárias na região do município de Bagé, Rio Grande do Sul, Brasil. Os objetivos incluiram a caracterização taxonômica da fauna de percevejos-do-mato e a implementação de estudo ecológico da diversidade desse grupo. Rede-de-varredura e guarda-chuva entomológico foram utilizados para amostrar árvores e arbustos em nove pontos ao longo de três dias consecutivos, em março de 2006. No total, 154 indivíduos de 32 espécies de Pentatomoidea foram coletados, quase todas novos registros para a fauna local. Matas com dossel mais alto apresentaram maior abundância e riqueza de espécies do que matas com dossel mais baixo. Das 32 espécies coletadas, 11 foram singletons e quatro foram doubletons. Não houve diferença na composição de espécies nos dois tipos de ambientes amostrados. A associação das espécies mais abundantes com o bioma Pampa é discutida. Embora baseada em um inventário rápido da fauna local, os resultados encontrados adicionam informações biológicas importantes sobre a fauna de percevejos-do-mato do bioma Pampa, especialmente aquela associada às matas ripárias.

PALAVRAS-CHAVE. Acanthosomatidae; Corimelaenidae; Pentatomidae; Scutelleridae; bioma Pampa.

Riparian forests are important features of any ecosystem, especially on grassland and savannah vegetation types, where they contain most of the arboreal species (Paz \& Bassagada 2002; Naiman et al. 2005). They provide services as maintaining river water quality and shelter for the fauna, as well as serving as natural corridors (Barrela et al. 2000). Human impacts can alter the state of riparian forests, affecting productivity and biodiversity (Naiman et al. 2005), and thus determining faunal richness.

In Brazil, riparian forests of different biomes and basins have been studied mainly from a botanical perspective (Rodrigues \& Leitão-Filho 2000), especially in the cerrado (Ribeiro et al. 2001). There has been a long interest in the grassland-forests dynamics of the Pampa biome (examples from
Rambo 1956 to Behling et al. 2005), but riparian forests in southernmost Brazil have received much less attention than elsewhere. Still very little is known on the fauna of the Pampa region overall (MMA 2000; Levinsohn \& Prado 2004), especially for invertebrates. As a consequence, there is an even larger gap on the knowledge of insect faunas associated to riparian forests in the southern part of Rio Grande do Sul.

Information on Pentatomoidea assemblage diversity on natural habitats is scant overall (Barcellos 2006; Schimdt \& Barcellos 2007), which is unwelcome since these insects are common, easily recognized, and there is taxonomic expertise for their use as indicators of impacted environments. Several pentatomoid species have known or potential agronomical impact (Panizzi et al. 2000), and studies on natural habitats are 
important to subsidize environmental management measures based on this group.

Knowledge on the Pentatomoidea of the Pampa biome comes mainly from museum lists (i.e. Berg 1878; Berg 1891; Pennington 1920; Pirán 1948 Buckup 1961; Grazia-Vieira \& Casini 1973). The few papers including surveys in selected areas (i.e. Lago \& Kaercher 1984, see also Schmidt \& Barcellos 2007) did not add much to the knowledge of the taxon in the region, as the information presented are usually partial (i.e. unidentified taxa or localities).

This is the first quantitative study of stink bug diversity in the Pampa biome, surveying riparian forests of brooks and rivers on three different sub-basins of Rio Grande do Sul state, southern Brazil, in the environs of the municipality of Bagé. The aim was two-fold: taxonomic characterization of the fauna and a primary ecological study of bug diversity. The latter specifically aimed to characterise environmental (forest structure/state) factors affecting Pentatomoidea species diversity and composition.

\section{MATERIALAND METHODS}

Study area. Bagé is a town located in the southern part of

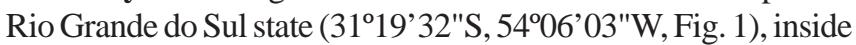
the Pampa biome, known in the WWF ecoregion classification as Uruguayan savanna (NT0710), which is characterized by expanses of grasslands and scattered savannah-like vegetation and riparian forests (Olson et al. 2001). Most of the study area is included in a region classified as of very high biological importance to the conservation of the biodiversity in Brazil (MMA 2000; 2007).

Sampling points (Fig. 1) covered riparian forests in three distinct drainage sub-basins around the Bagé area: Santa Maria, Negro and Jaguarão. Each sub-basin had three sampled sites. The areas to the west of Bagé were within the Ponche Verde high conservation priority area; eastward points were on the Campos de Jaguarão, also deemed a high conservation priority area (MMA 2007). Sampling points were chosen for logistic reasons, closer to roads and bridges, but never within urban areas.

Most environmental descriptors of the sampled riparian areas were related, forming two main habitats: one with rocky margins and transparent running water, apparently associated to better preserved forests (three sites with taller canopy and higher plant species richness), and muddy margins with dark, slow flowing water associated to poorly preserved forests (six sites with shorter canopy, shorter plant species richness).

Sampling. Sweeping net was used on the border between riparian forests and adjacent fields to sample the herb layer, and beating tray was used to sample trees and shrubs on the border of sampling sites. Sampling included one person working for fixed periods of time (never less than $30 \mathrm{~min}$ ). We attempted to cover the longest possible section of the river at each sampling point. The total sampling time on each subbasin was the same (180 min). Sampling was carried out during three consecutive days, from March $28^{\text {th }}$ to $30^{\text {th }} 2006$.

Adults were slain in the field with killing jars and mounted in the lab; whenever necessary, juveniles were kept in pots with wet paper, taken to the lab and reared until reach adulthood. Identification was to species level whenever possible. Given the present status of the taxonomic knowledge on Corimelaenidae, Pentatomidae-Edessinae and Scutelleridae in the Neotropical region, insects in those families were identified down to genus level and further separated in morphospecies. This is the adopted practice in the LES-UFRGS, since 2003, for faunistic surveys carried out in natural areas of Rio Grande do Sul. To permit comparisons among different surveys, we used the same identification number for each morphospecies deposited in the collection.

Data analysis. Quantitative data were analysed for alpha diversity (species diversity and species abundance distribution, SAD) and beta diversity (species composition) using PASt software (Hammer et al. 2001). Species richness was compared between taller and shorter forests using sample based rarefaction (species accumulation function) and associated confidence intervals. Species abundance distributions for the whole fauna and for either vegetation structure were fitted to three models: geometric, broken stick, log-series and log-normal. Species composition between taller and shorter forests was compared with an ANOSIM test with 10.000 randomisations.

\section{RESULTS}

Overall 154 individual Pentatomoidea were captured, 45 of them as nymphs; 32 species were found (Table I). Species are distributed on four families and six subfamilies (Table I). The Pentatominae subfamily was the largest group including more than half the species $(S=18)$ and about two third of the individuals $(n=104)$. No new taxon records were detected for the Pampa biome, although almost all species are new records for the local fauna; Acanthosomatidae $(\mathrm{S}=1 ; \mathrm{n}=11)$, Corimelaenidae $(\mathrm{S}=3 ; \mathrm{n}=14)$ and Scutelleridae $(\mathrm{S}=3 ; \mathrm{n}=4)$ have never been listed for the region before. From the laboratory rearing of immature insects, for the first time it was possible to record information on developmental stages of Chinavia aseada (Rolston), Kermana fucosa (Berg, 1892) and Hellica nitida Haglund, 1868.

Taller forest canopy sites had higher abundance overall (107 individuals, of which 30 nymphs) than shorter forest canopy sites (47 individuals, 15 nymphs). The former also had significantly higher species richness than shorter forest canopy sites (Fig. 2a), although the species accumulation curves appear different, with lower forests canopy more linear and taller ones starting to tamper (not shown). Of the 32 species, 11 were singletons and four were doubletons. Thus, half the species sampled had low sampling abundances. The overall SAD for the assemblage appears almost linear in a log plot and significantly fits only the logseries $(\alpha=12.27 ; x=0.926 ; p=$ 0.001 , Fig. $2 b)$. Both taller $(\alpha=7.81 ; x=0.932 ; p=0.035)$ and 


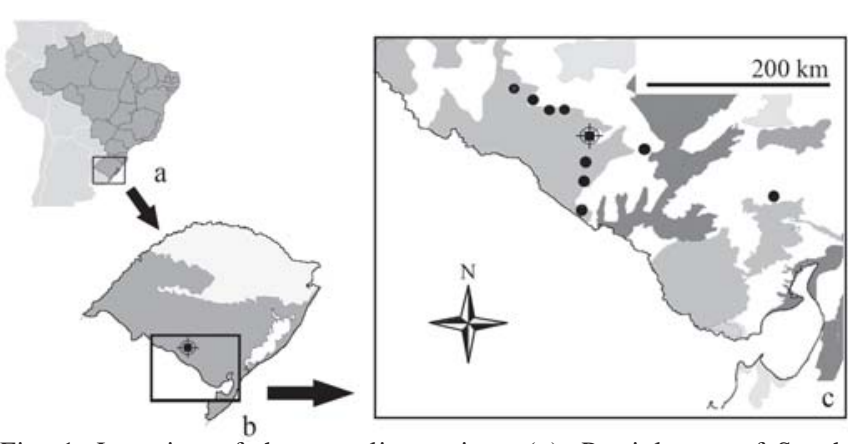

Fig. 1. Location of the sampling points. (a), Partial map of South America with Rio Grande do Sul state in detail; (b), Rio Grande do Sul map (area of the Pampa biome in gray); (c), Sampled region $(\phi=$ location of Bagé, RS, Brazil, 31¹9'32"S, 5406'03"W GR; • sampling points; grey shadows in Fig. 1c delimit areas considered important to the conservation of the biodiversity in Brazil, according to MMA 2007).

shorter forests $(\alpha=10.66 ; x=0.815 ; p=0.001)$ had very similar SADs and also significantly fit the logseries only (Fig. 2c).

The ANOSIM test reveals no differences for pentatomoid species composition between the two environments differing in vegetation structure, either for the qualitative (Jaccard similarity index, rank within $=6.67$, rank between $=8.89, R=$ $0.30, p=0.294$ ) or quantitative (Morisita similarity index, rank within $=8.33$, rank between $=7.78, R=-0.07, p=0.497$ ) assessments. This is in spite $78.1 \%$ of the species being exclusive to either of the environments $(40.6 \%$ of the species when not counting singletons, eight to taller forests, five to shorter forests).

\section{DISCUSSION}

This is the first Neotropical study to compare the ecological structure of pentatomoid assemblages in different natural habitats, linked to a taxonomic inventory of the sampling site. Barcellos (2006) and Schmidt \& Barcellos (2007) also presented pentatomoid inventories from a coastal and an Atlantic Forest area, respectively, but no quantitative comparisons among habitats were attempted. However, all ecological results presented here are tentative: more effort is needed for a deeper analysis.

The most abundant (>5\%) species found in our survey are widely distributed in the southern part of South America, a biogeographic pattern apparently common for insects in this family (i.e. Grazia 1997; Fortes \& Grazia 2005; Campos \& Grazia 2006). However, the association of pentatomoids to specific natural habitats is almost largely ignored. Two of the most common species, Dichelops furcatus (Spinola, 1852) and Mormidea quinqueluteum (Lichtenstein, 1796), are considered crop pests (Panizzi et al. 2000). Although Schmidt \& Barcellos (2007) found that species related to agroecosystems can be also abundant in natural environments, our results show this is not a rule. The other particularly abundant species, $H$. nitida, Odmalea basalis (Walker, 1867) and Thyanta humilis Bergroth, 1891 are not recorded in association to agroecosystems. On the other hand, more than half of the singletons and doubletons are species very common in collections, widely distributed in the Neotropics and generally associated with crops (Table I). In the Bagé region there are few planted cultures, with most areas devoted to extensive cattle farming.

Besides information on distribution and adult morphology (Rider \& Chapin 1991), nothing is known about T. humilis (Figs. 3 and 4), the most abundant species here (Table I). Thyanta Stal, 1862 is one of the most diverse genera among Pentatominae, with about $50 \mathrm{spp}$. found across the American continent (Rider \& Chapin 1991). Its species are considered polyphagous (Panizzi et al. 2000), although few have a record of host plant; habitat information on the great majority

Table I. Pentatomoidea (Hemiptera) recorded in the riparian forests of Bagé region, RS, Brazil, from March $28^{\text {th }}$ to $30^{\text {th }} 2006$ (S, number of species; $n$, number of individuals; $F$, frequency).

\begin{tabular}{|c|c|c|}
\hline Identification & $\mathrm{n}$ & $\mathrm{F}(\%)$ \\
\hline \multicolumn{3}{|l|}{ Acanthosomatidae $(\mathrm{S}=1)$} \\
\hline \multicolumn{3}{|l|}{ Blaudinae } \\
\hline Hellica nitida Haglund, 1868 & 11 & 7.1 \\
\hline \multicolumn{3}{|l|}{ Corimelaenidae $(S=3)$} \\
\hline \multicolumn{3}{|l|}{ Corimelaeninae } \\
\hline Galgupha sp.1 & 6 & 3.9 \\
\hline Galgupha sp.2 & 5 & 3.2 \\
\hline Galgupha sp.3 & 3 & 1.9 \\
\hline \multicolumn{3}{|l|}{ Pentatomidae $(S=25)$} \\
\hline \multicolumn{3}{|l|}{ Asopinae $(S=2)$} \\
\hline Brontocoris nigrolimbatus (Spinola, 1852) & 1 & 0.6 \\
\hline Podisus nigrispinus (Dallas, 1851) & 1 & 0.6 \\
\hline \multicolumn{3}{|l|}{ Edessinae $(S=5)$} \\
\hline Brachystethus geniculatus (Fabricius, 1787) & 1 & 0.6 \\
\hline Edessa meditabunda (Fabricius, 1784) & 7 & 4.5 \\
\hline E. rufomarginata (De Geer, 1773) & 2 & 1.3 \\
\hline Edessa sp.1 & 3 & 1.9 \\
\hline Edessa sp.2 & 6 & 3.9 \\
\hline \multicolumn{3}{|l|}{ Pentatominae $(S=18)$} \\
\hline Acledra kinbergii (Stål, 1859) & 4 & 2.6 \\
\hline Arvelius albopunctatus (De Geer, 1773) & 1 & 0.6 \\
\hline Chinavia longicorialis (Breddin, 1901) & 4 & 2.6 \\
\hline C. aseada (Rolston, 1983) & 2 & 1.3 \\
\hline Dichelops furcatus (Fabricius, 1775) & 18 & 11.6 \\
\hline Euschistus picticornis (Stål, 1872) & 3 & 1.9 \\
\hline E. irroratus Bunde, Grazia \& Mendonça Jr., 2006 & 2 & 1.3 \\
\hline Kermana fucosa (Berg, 1892) & 1 & 0.6 \\
\hline Loxa deducta (Walker, 1867) & 1 & 0.6 \\
\hline Mayrinia curvidens (Mayr, 1864) & 1 & 0.6 \\
\hline Mormidea notulifera Stål, 1860 & 4 & 2.4 \\
\hline M. paupercula Berg, 1878 & 6 & 3.9 \\
\hline M. quinqueluteum (Lichtenstein, 1796) & 15 & 9.7 \\
\hline Odmalea basalis (Walker, 1867) & 11 & 7.1 \\
\hline Pallantia macunaima Grazia, 1980 & 5 & 3.2 \\
\hline Piezodorus guildinii (Westwood, 1837) & 1 & 0.6 \\
\hline Proxys albopunctulatus (Palisot de Beauvois, 1805) & ) 1 & 0.6 \\
\hline Thyanta humilis Bergroth, 1891 & 24 & 15.6 \\
\hline \multicolumn{3}{|l|}{ Scutelleridae $(S=3)$} \\
\hline \multicolumn{3}{|l|}{ Pachycorinae } \\
\hline Tetyra poecila (Berg, 1878) & 2 & 1.3 \\
\hline Orsilochides sp. 1 & 1 & 0.6 \\
\hline Symphylus sp.1 & 1 & 0.6 \\
\hline
\end{tabular}



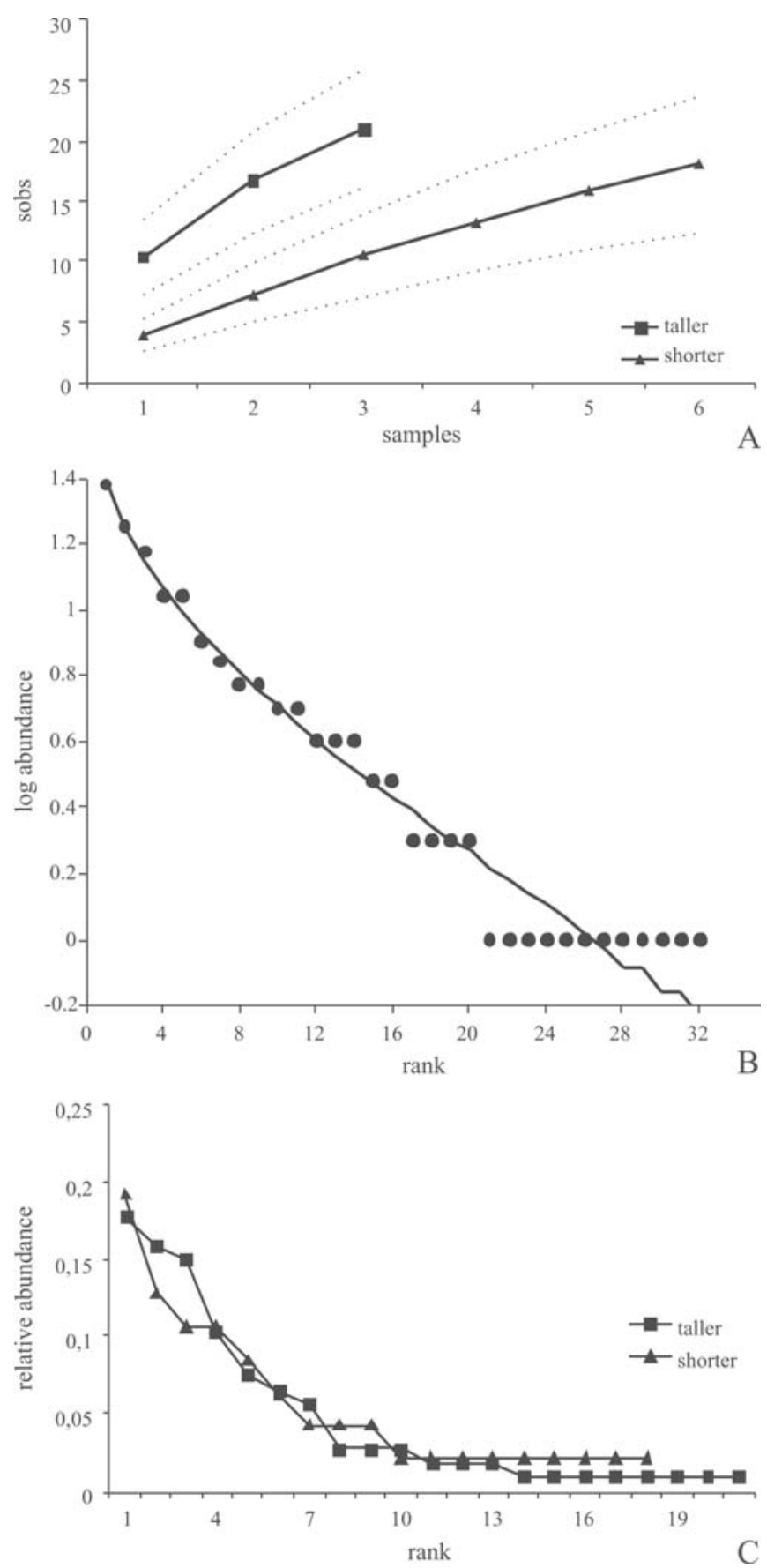

Fig. 2. Pentatomoidea diversity in Bagé region, RS. (a), sampled based rarefaction of species richness for taller (squares) and shorter (triangles) riparian forest types with $95 \%$ confidence intervals (stippled lines); (b), Whittaker plot for the overall species abundance distribution, with the fit to the log series model shown as a line; (c), species abundance distribution for taller and shorter riparian forest types (relative abundances shown to allow visual comparison).

neotropical species of Thyanta is rare. After a two year sampling regime in northwestern RS, in an Atlantic forest area, T. humilis (cited as Thyanta patruelis Stål) represented less than $0.5 \%$ of the total abundance (Schmidt \& Barcellos 2007). Barcellos (2006) found a high abundance of T. humilis in a survey of two vegetation types of the Coastal area of Rio
Grande do Sul. Based on these results, it seems probable that T. humilis is associated with more open habitats, like the ones found in the Pampa biome.

Species on the genera Dichelops Spinola, 1837 and Mormidea Amyot \& Serville, 1843 are relatively better known because of the association to agroecosystems (Grazia 1978; Rolston 1978b; Panizzi et al. 2000). D. furcatus is found feeding mainly from legumes, although eventually also on solanaceans, rosaceans and grasses (Grazia 1978; Panizzi et al. 2000). In agroecosystems, $D$. furcatus is rarely found in large numbers (Panizzi et al. 2000), which contrasts with this study on more natural settings. Species of Mormidea are included in a pentatomid group associated to grasses (Panizzi 2000), and $M$. quinqueluteum is recorded on various cultivated grasses in southern Brazil, being considered one of the main rice pests (Panizzi et al. 2000). A predominance of grass-associated species in the Pampa biome is expected, given that the natural vegetation is very rich in this taxon. Among the species sampled in Parque Estadual do Turvo in the Atlantic forest biome, Mormidea ypsilon (Linnaeus, 1758), a species with more northern distribution (Rolston 1978a), was also among the most abundant taxa (Schmidt \& Barcellos 2007).

The other two abundant species in our samples, the acanthosomatid $H$. nitida and the pentatomid $O$. basalis (Figs. 5-9), were never cited in previous local pentatomid surveys, and nearly nothing is known about their biology. The genus Hellica has only three described species, and is restricted to northern Argentina and southern Brazil (Froeschner 1999); $H$. nitida is the only species for Brazil. The genus Odmalea has six described species (Rider 1994), with O. basalis considered rare (Barcellos 2006). A high abundance for both species in the present work indicates they could be associated to habitats in the Pampa biome, particularly riparian forests; the lack of information on these species, as well as its supposed rare condition, would then reflect the little attention given to the invertebrate fauna in this region.

Individuals of families Corimelaenidae and Scutelleridae are commonly collected in pentatomoid surveys, but their identification at species level was not possible. The taxonomy of both families is fragmentary in the Neotropics. Species of Galgupha Amyot \& Serville, 1843 are very common and abundant in the surveys carried out by our team in Rio Grande do Sul, but difficulties in identification limits the knowledge about them. The only monograph was published a long time ago (McAtee \& Malloch 1933), in which six species were recorded to southern Brazil. In a preliminary identification effort of specimens from our surveys since 2003 (J. Grazia, unpublished data), more than 15 morphospecies were assigned. Although less diverse and less abundant, information on Scutelleridae in natural habitats is also scarce in the Neotropics. In Brazil, an account of the data was made by Costa Lima (1940), and many of the species collected in recent surveys (Barcellos 2006; Schmidt \& Barcellos 2007; J. Grazia unpublished data) are included in genera that need to be revised. Both corimelaenids and scutellerids are important elements of pentatomoid fauna in natural areas of southern 

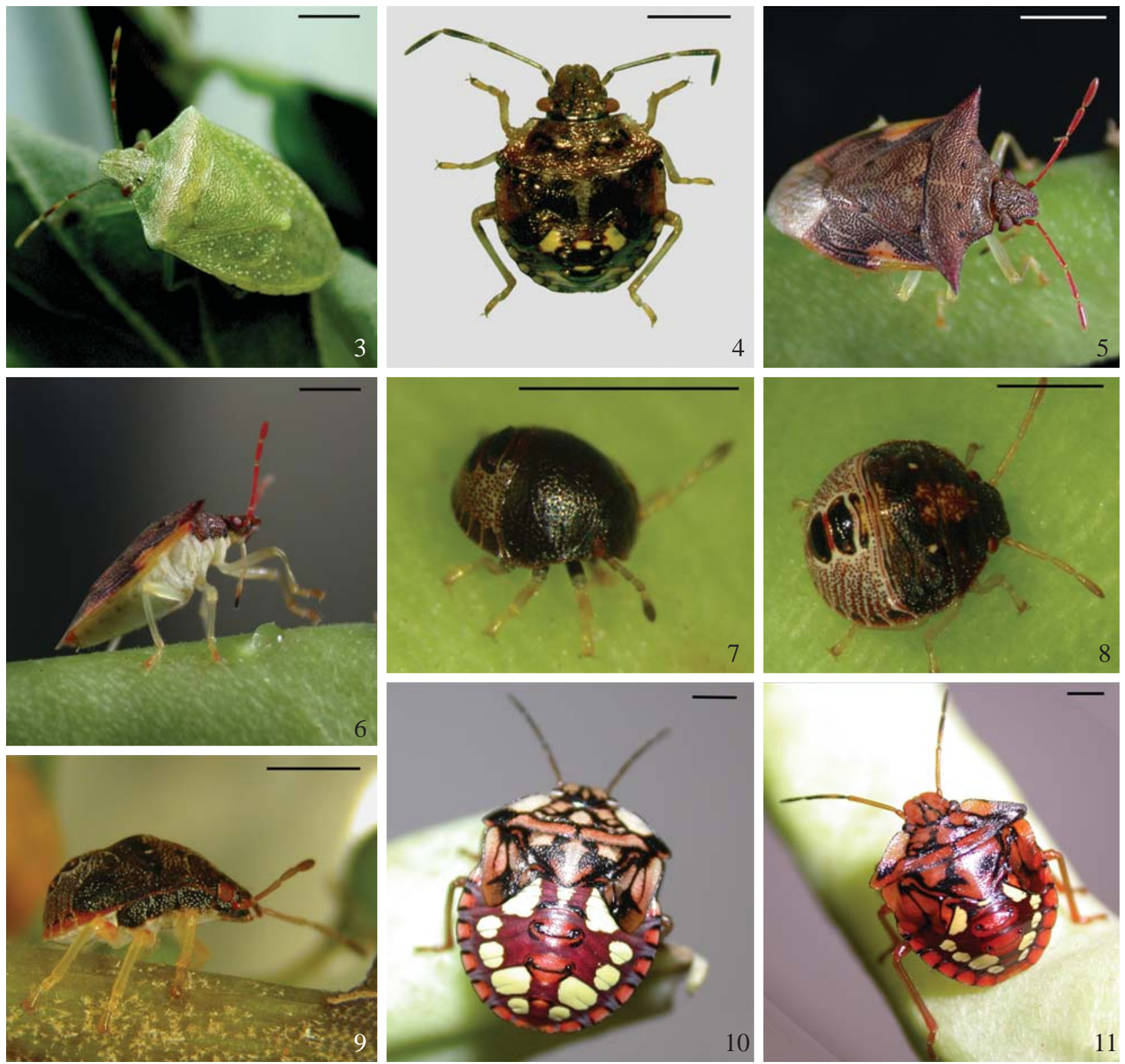

Figs. 3-11. Pentatomoidea of Bagé region. 3 and 4, Thyanta humilis Bergroth: adult (3) and nymph (4); 5-9, Odmalea basalis (Walker): adult (5 and 6), second instar nymph (7), fourth instar nymph (8) and fifth instar nymph (9); 10 and 11, Chinavia aseada (Rolston): fifth instar nymphs, light (10) and dark (11) morphs (scale bar= $2 \mathrm{~mm}$ ).

Brazil, and an accurate description of its species are crucial.

Vegetation structure seems to be an important factor determining pentatomoid richness in the Pampa biome: invertebrates in general respond positively to vegetation heterogeneity/diversity in structure (Tews et al. 2004). Pentatomoids may also depend on the variety of plants found in a given site, a trend observed in other Heteroptera in general (Barcellos 2006; Gossner 2006; Mitchell 2006). No other data comparing distinct forest types appear to be available for this taxon, since other standardized studies did not accomplished such tests (Barcellos 2006; Schmidt \& Barcellos 2007). Although we do not have details on variables as local plant species richness, cover and canopy structure, there is a strong indication that such characteristics may be invaluable to understand the distribution of stink bugs in riparian forests.

Lately, assessments of the value of SADs suggested the hollow curve pattern to be universal and useful for ecological comparisons (e.g. McGill et al. 2007). Magurran (2004) stated that SADs fitting the log series model denote a preponderance of rare species, and perhaps a biological interpretation that a few important factors drive species abundances and composition. It seems that the narrow riparian forests of the Pampa grasslands could exert a strong influence on its pentatomoid fauna, probably in terms of abiotic ecological factors as sunlight and higrothermal stress. Schmidt \& Barcellos (2007) did not fit models to the SAD of 
Pentatomoidea and their curve is hollow as reported here but with the dominant species apparently much more abundant in comparison with the rare species. It remains to be seen whether different environments reveal different SADs for these herbivores.

The lack of differences in species composition between taller or shorter forests is also not unexpected because phytophagous pentatomoids are considered generalists in terms of host plant choice (Panizzi 2000; Panizzi et al. 2000). Asopinae are predatory but here only two species appear, as singletons, and thus do not influence the pattern significantly. We can expect only very different vegetation structures to show any difference in stink bug species composition, even though agroecosystem pests characteristic of highly managed short vegetation (as soybean) have been also found deep in well preserved tall forests (Schmidt \& Barcellos 2007).

Taller forests may be the result of better preservation of the environment, specially related to cattle grazing and treading, the main antropogenic factor in the sampled region. However, without detailed information on the history of management practices inherent to a rapid inventory such as this, we have chosen not to correlate vegetation structure and degree of forest preservation. Future studies would certainly add much to our knowledge of faunal responses to human disturbance by taking in such a comparison.

Although based on a rapid assessment protocol of faunal inventories, our results add important bioecological information to and allow us to raise questions concerning the pentatomoid fauna of the Pampa biome, especially associated to riparian forests. Species richness was considerably high if compared to results of other recent surveys using the same sampling methods, but with much higher sampling effort (i.e. Barcellos 2006; Schmidt \& Barcellos 2007). Although a strong seasonality in higher latitudes is characteristic for stink bugs (Panizzi et al. 2000), and at the end of the summer there is usually an increased abundance of adults and late instars, the identification and use of immatures (i.e. Figs. 4, 7-11) to evaluate local diversity was very important. Such bioecological factors should be taken into account for future biodiversity studies with the group, especially rapid biodiversity inventories like the one carried out here.

Acknowledgments. This work was partially supported by a CNPq grant (Edital Universal, n. 473137/2004-6). We thank Anne G. Cohen for help during field and laboratory triage, and Aline Barcellos for the identification of Scutelleridae.

\section{REFERENCES}

Barcellos, A. 2006. Hemípteros terrestres, p. 198-209. In: F. G. Becker; R. A. Ramos L. de A. Moura (Orgs.). Região da Lagoa do Casamento e dos Butiazais de Tapes, Planície Costeira do Rio Grande do Sul. Brasília, Ministério do Meio Ambiente, 388 p. Available at: <http://www.mma.gov.br>

Barrela, W.; M. Petrere Jr.; W. S. Smith \& L. F. A. Montag. 2000. As relações entre as matas ciliares, os rios e os peixes, p. 187-207. In: R.R. Rodrigues \& H. F. Leitão Filho (Eds.). Matas Ciliares: conservação e recuperação. São Paulo, EDUSP, 320 p.
Behling, H.; V. D. Pillar \& S. G. Bauermann. 2005. Late Quaternary grassland (Campos), gallery forest, fire and climate dynamics, studied by pollen, charcoal and multivariate analysis of the São Francisco de Assis core in western Rio Grande do Sul (southern Brazil). Review of Palaeobotany Palynology 133: 235-248.

Berg, C. 1878. Hemiptera Argentina enumeravit speciesque novas descripsit. Anales de la Sociedad Cientifica Argentina 5: 231260.

Berg, C. 1891. Nova Hemiptera faunarum argentinae et uruguayiensis Anales de la Sociedad Cientifica Argentina 32: 164-175.

Buckup, L. 1961. Os pentatomídeos do Estado do Rio Grande do Sul (Brasil) (Hemiptera-Heteroptera-Pentatomidae). Iheringia, série Zoologia 16: 1-24.

Campos, L. A. \& J. Grazia. 2006. Análise cladística e biogeografia de Ochlerini (Heteroptera, Pentatomidae, Discocephalinae). Iheringia, série Zoologia 96: 147-163.

Costa Lima, A. M. da 1940. Insetos do Brasil, $2^{\circ}$ Tomo. Capitulo XXII. Hemipteros. Rio de Janeiro, Escola Nacional de Agronomia, $351 \mathrm{p}$.

Fortes, N. D. F. de \& J. Grazia. 2005. Revisão e análise cladistica de Serdia Stål (Heteroptera, Pentatomidae, Pentatomini). Revista Brasileira de Entomologia 49: 294-339.

Froeschner, R. C. 1999 [2000]. Revision of the South American genus Hellica Stål (Heteroptera: Acanthosomatidae). Journal of the New York Entomological Society 107: 164-170.

Grazia, J. 1978. Revisão do gênero Dichelops Spinola, 1837 (Heteroptera, Pentatomidae, Pentatomini). Iheringia, Série Zoologia 53: 1-119.

Grazia, J. 1997. Cladistic analysis of the Evoplitus genus group of Pentatomini (Heteroptera: Pentatomidae). Journal of Comparative Biology 2: 43-48.

Grazia-Vieira, J. \& C. E. Casini. 1973. Lista preliminar dos heterópteros uruguaios da região nordeste: Pentatomidae e Coreidae (Insecta: Heteroptera). Iheringia, série Zoologia 44: 55-63.

Gossner, M. 2006. The importance of silver fir (Abies alba Mill.) in comparison to spruce (Picea abies (L.) Karst.) and oak (Quercus petraea (Matt.) Liebl.) for arboreal Heteroptera communities in Bavarian forests. Waldoekologie online 2: 90-105.

Lago, I. C. S. \& F. Kaercher. 1984. Hemípteros de ocorrência nas regiões Encosta do Sudeste, Serra do Sudeste, Campanha e Litoral do Rio Grande do Sul. Agros 19: 92-103.

Levinsohn, T. M. \& P. I. Prado. 2002. Biodiversidade Brasileira. Síntese do estado atual do conhecimento. São Paulo, Contexto Acadêmico, 245 p.

Magurran, A. E. 2004. Measuring Biological Diversity. Oxford, Blackwell Publishing, $260 \mathrm{p}$.

McGill, B. J.; R. S. Etienne; J. S. Gray; D. Alonso; M. J. Anderson; H. K. Benecha; M. Dornelas; B. J. Enquist; J. L. Green; F. He; A. H. Hurlbert; A. E. Magurran; P. A. Marquet; B. A. Maurer; A. Ostling; C. U. Soykan; K. I. Ugland \& E. P. White. 2007. Species abundance distributions: moving beyond single prediction theories to integration within an ecological framework. Ecology Letters 10: 995-1015.

McAtee, W. L. \& J. R. Malloch, 1933. Revision of the subfamily Thyreocorinae of the Pentatomidae (Hemiptera-Heteroptera). Annals of Carnegie Museum 21: 191-411.

Mitchell, P. 2006. Polyphagy in true bugs: a case study of Leptoglossus phyllopus (L.) (Hemiptera, Heteroptera, Coreidae), p. 1117-1134. In: W. Rabitsch (ed.). Hug the bug - For love of true bugs. Festschrift zum 70 Geburtstag von Ernst Heiss, Denisia 19. Linz, Biologiezentrum der Oberösterreichische Landeesmuseen, $1184 \mathrm{p}$.

MMA (Ministério do Meio Ambiente, Brasil). 2000. Avaliação e ações prioritárias para conservação da biodiversidade da Mata Atlântica e Campos Sulinos. Brasília, Ministério do Meio Ambiente, 40 p. Available at: 〈http://www.mma.gov.br>

MMA (Ministério do Meio Ambiente, Brasil). 2007. Áreas Prioritárias para a Conservação, uso sustentável e repartição dos benefícios da biodiversidade brasileira. Brasília, Ministério do Meio Ambiente, 300 p. Available at: 〈http://www.mma.gov.br〉 
Naiman, R.J.; H. Decamps \& M. E. McClain. 2005. Riparia: Ecology, Conservation, and Management of Streamside Communities. San Diego, Academic Press, 448 p.

Pennington, M. S. 1920. Lista de los Hemipteros Heteropteros de la Republica Argentina. Primera parte. Buenos Aires, Editora do autor, $47 \mathrm{p}$.

Pirán, A. A. 1948. Contribución al conocimiento de la dispersion geografica de los hemípteros neotropicales. Acta Zoologica Lilloana 5: 5-17.

Olson, D. M.; E. Dinerstein; E. D. Wikramanayake; N. D. Burgess; G. V. N. Powell; E. C. Underwood; J. A. D'Amico; I. Itoua; H. E. Strand; J. C. Morrison; C. J. Loucks; T. F. Allnutt; T. H. Ricketts; Y. Kura; J. F. Lamoreux; W. W. Wettengel; P. Hedao \& K. R. Kassem. 2001. Terrestrial ecoregions of the World: a new map of Life on Earth. BioScience 51: 933-938.

Panizzi, A. R. 2000. Suboptimal nutrition and feeding behavior of hemipterans on less preferred plant food sources. Anais da Sociedade Entomológica do Brasil 29: 1-12.

Panizzi A. R.; J. E. McPherson; D. J. James; M. Javahery \& R. M. McPherson. 2000. Stink bugs (Pentatomidae), p. 421-474. In: C. W. Schaefer \& A. R. Panizzi (Eds.). Heteroptera of economic importance. Boca Raton, CRC Press, 856 p.

Rambo, B. 1956. A fisionomia do Rio Grande do Sul. $2^{\circ} \mathrm{ed}$. Porto Alegre, Selbach, $456 \mathrm{p}$.
Ribeiro, J. F.; C. E. L. Fonseca \& J. C. Sousa-Silva (Eds.). 2001. Cerrado: caracterização e recuperação de matas de galeria. Planaltina, EMBRAPA Cerrados, 899 p.

Rider, D. A. 1994. A generic conspectus of the Tribe Procleticini Pennington (Heteroptera, Pentatomidae), with the description of Parodmalea rubella, new genus and species. Journal of New York Entomological Society 102: 193-221.

Rider, D. A. \& J. B. Chapin. 1991. Revision of the genus Thyanta Stål, 1862 (Heteroptera: Pentatomidae). I. South America. Journal of New York Entomological Society 99: 1-77.

Rodrigues, R. R. \& H. de F. Leitão Filho. 2000. Matas Ciliares: conservação e recuperação. São Paulo, EDUSP, 320 p.

Rolston, L. H. 1978a. A revision of the genus Odmalea Bergroth (Hemiptera: Pentatomidae). Journal of the New York Entomological Society 86: 20-36.

Rolston, L. H. 1978b. A revision of the genus Mormidea (Hemiptera: Pentatomidae). Journal of the New York Entomological Society 86: $161-219$.

Schmidt, L. S. \& A. Barcellos. 2007. Abundância e riqueza de espécies de Heteroptera (Hemiptera) do Parque Estadual do Turvo, sul do Brasil: Pentatomoidea. Iheringia, série Zoologia 97: 73-79. 